\section{FICTION BOOK REVIEW}

\section{Antigona and Me}

Kate Clanchy. London, UK: Picador (Pan Macmillan), 2009. ISBN-13: 978-0-33044-933-5. Price: $£ 7.00$.

Pages: 273 (paperback)

A review of this book in a national newspaper caught my attention; the author grew up in Edinburgh and I have been interested in her work as a poet over the years. Her poetry is quintessentially English, very poised and beautifully written, often exploring topics of femininity and motherhood. This book is the author's first venture into prose and explores her personal relationship with a Kosovan refugee to whom she impulsively offers a cleaning job at their first meeting in the street outside her home. Antigona is a victim of the 1999 Kosovan war and Clanchy recounts Antigona's own horrific experience of the war and her dramatic escape to London. Her three beautiful and wide-eyed children come with her to London but she has endured six abortions and marital rape, with domestic violence causing several spontaneous abortions. Their journey succeeds largely through the kindness of strangers; a city gent at Victoria station put them in a London taxi with a $£ 20$ note and directions to a local church.

Antigona becomes renowned in her East London community. She is the only Albanian woman who has dared to divorce her wife-beating husband in the English courts and who is unbowed, growing richer and stronger. Other similar women seek her counsel but always go back to their husbands. Antigona is also the invisible untaxed person who helps a traditional middle-class English family and loves their children as her own. It is estimated that there are many more than three million private cleaners in the UK, almost all working below the radar of the Inland Revenue. Apparently even the Home Office is cleaned by illegal migrant labour. I also employ an East European cleaner and appreciate how these domestic relationships become very close and sometimes very infuriating.

Antigona graduates from cleaner to nanny and becomes legal with temporary leave to remain in the UK. Being a refugee in the UK is marked by immigration bureaucracy that is impenetrable when you find yourself having to negotiate it all on someone's behalf. My family helped to sort out our cleaner's relative who was picked up by immigration officials and sent to a Detention Centre in Devon over Christmas. What constitutes an economic migrant and a bona fide refugee all becomes immeasurably blurred. It is heartbreaking when the individuals concerned have developed strong bonds and friendships within the local community but face deportation. The book does not have a happy ending.

Working women face the reality of needing cleaners and collude in the fact that the house is their responsibility whether or not they are working the same hours as their male partners. Kate Clanchy explores these themes and describes the epiphanies she and her working friends experience by the "mopped-ness and fresh tidiness" of their homes after employing Antigona. We have no proper serious way of talking about cleaning in this country and so we tend to ignore it. With professional motherhood later than ever before, women who try to return to work post-children find they have much more housework to do and often feel too tired to do it. Clanchy's friends phone each other and discuss a refugee who is good at mopping and don't care if this is feminism or not.

So should you buy this book? Clancy has tithed proceeds from sales of the book to Antigona and her family. To protect Antigona's privacy, all names and locations have been changed and members of her family have become composite characters so to be unidentifiable. The book gives great insight into the lives of migrant women living in the UK who face an immense clash of cultures but yet are utterly bewitched by our affluent consumerism. Above all, it is a book written with great compassion and is a tribute to the friendship of two women who, to quote the author, are "chalk and cheese". I thoroughly recommend it.

Reviewed by Ailsa E Gebbie

Director of Family Planning Services, NHS Lothian, Edinburgh, UK

J Fam Plann Reprod Health Care 2011;37:7. doi:10.1136/Ifprhc.2010.0021 